\title{
Adaptation of Bivalve Molluscs to Environmental Conditions in the Coastal Region of El Jadida (Morocco): Case of Mytilus Galloprovincialis
}

\author{
Essedaoui Aafaf, Professor \\ University of Chouaib Doukkali/ Faculty of Science of El Jadida / \\ Laboratory of Biochemistry, Nutrition, Valorization of Natural Resources/ \\ Nutritional Physiopathology and Toxicology /Morocco \\ Regional Center of the Trades of Education and Training Casablanca - Settat, \\ Section of El Jadida/Department of Life and Earth Sciences/ Morocco.

\section{Messaoudi Abdelfettah, Master Student \\ Ferssiwi Abdesslam, Professor \\ Massar Redouane, PhD Student \\ Bitar Abdelali, Professor} \\ University of Chouaib Doukkali/ Faculty of Science of El Jadida / \\ Laboratory of Biochemistry, Nutrition, Valorization of Natural Resources/ \\ Nutritional Physiopathology and Toxicology /Morocco
}

doi: 10.19044/esj.2017.v13n18p226 URL:http://dx.doi.org/10.19044/esj.2017.v13n18p226

\begin{abstract}
The aim of this study is to assess the impact of industrial pollution on the growth and reproduction of the mussel Mytilus galloprovincialis from coastal region of El Jadida (Morocco). To this aim, three stations (S1, S2 and S3) are chosen according to their proximity to the industrial effluents of the chemical complex. The seawater and mussels $(N=100 /$ station $)$ samples have been randomly and monthly collected for a period of 6 months (February-July 16). Mussels are distributed in 6 classes of size and measures of condition index and gonadic index are performed in the most common size classes. The results of the analysis of physicochemical parameters of the water show spatio-temporal variations with an acidic $\mathrm{pH}$, high temperature and low salinity in the station near of industrials effluents. Regarding condition index and the gonadic index, there is no significant difference between the mussels collected from the reference station (S2) and the polluted station (S3). This can be explained partly by the adoption of a strategy of adaptation to the environmental stress caused by the industrial pollution.
\end{abstract}


Keywords: Industrial Pollution - Mytilus galloprovincialis - Condition Index - Gonadic Index - - El Jadida (Morocco)

\section{Introduction}

The coastline of the region of El Jadida is subject to changes imposed by the urban agglomeration and industrial infrastructure including processing units phosphates located at Jorf-Lasfar in the South of El Jadida. These various activities generate a change in the living environment of species colonizing this site by contamination that can affect the quality of life and threaten the ecological balance, and thus endanger animal and human health. Indeed, the coast of Jorf-Lasfar denotes high values of cadmium in seawater (Kaimoussi and al., 2001) and in marine animals especially the mussel Mytilus galloprovincialis (Essedaoui and al., 2001; Merzouki and al., 2009) and polychaete annelids (Ferssiwi and al., 2004) from the sites close to the effluence of phosphate processing industries in Jorf-Lasfar.

Growth is defined as the measure of the increase in size and weight of the individual, depending on time and environmental factors (biotic and abiotic). In a population of bivalve mollusc, the dynamic weight is closely related to the reproductive activity; it is disturbed by a processes associated with reproduction (Le Pennec, 1981). The temporary accumulation of reserves for the production of gametes occasions a sudden loss of weight, slows or a stops growth (Barille, 1996). This author suggests separating these two processes to accurately determine the influence of environmental constraints on growth or reproduction. Hence, there is a need to simultaneously undertake a study of growth and reproduction in bivalve mollusc.

The study of the biology and dynamics of mussel populations has an undeniable scientific interest. It is a reflection of overall response of organism and better reflects the effects of the contamination on the body and on the potential population (Amiard and Amiard-Triquet, 2008). These studies can provide the baseline data needed for all commercial exploitation of this mollusc, as well as for use in biomonitoring coastal (Mussel Watch). However, the mussels have long been considered sentinel species because of their relative immobility and their sedentary lifestyle that makes them acquire a broad spectrum of sensitivities to pollution thus polluting their storage capacity (Farrington, 1991).

In this study, we propose to evaluate the impact of industrial pollution and changes in physico-chemical parameters on growth (Condition Index) and reproduction (Gonadal Index) in the mussel Mytilus galloprovincialis collected at the stations prospected in the coastline from the 
region of El Jadida. These stations have been chosen according to their proximity in the industrial effluents of the chemical complex.

This study has the following objectives:

* To measure the abiotic and biotic parameters in the different study sites S1, S2 and S3 located respectively at $28 \mathrm{~km}$ and $17 \mathrm{~km}$ to the North and $1 \mathrm{~km}$ South from industrial effluents.

* To determine the condition index and the gonadic index in mussels belonging to the most frequent size classes in the prospected stations to detect a possible adaptation to the changing conditions of the environment.

\section{Materials and methods}

To achieve the objectives, three stations have been selected at the coastline in the region of El Jadida (Morocco) according to their proximity to industrial effluents of chemical complex located at the coast of Jorf-Lasfar (Fig. 1).

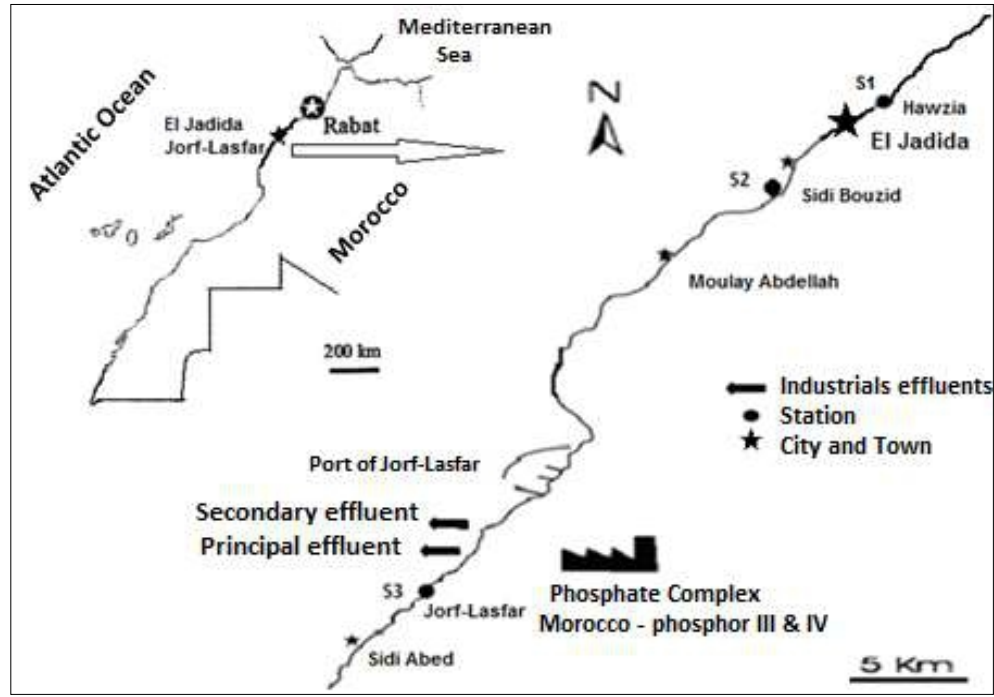

Figure.1. Geographical location of prospected stations at El Jadida -Morocco

\section{Location of the prospected stations}

* Station "Hawzia" (S1): located $1 \mathrm{~km}$ North of the city of El Jadida and $28 \mathrm{~km}$ North of effluents of the phosphate complex in Jorf-Lasfar. This site is characterized by the absence of sources of pollution.

* Station "Sidi Bouzid" (S2): this is a beach resort located $5 \mathrm{~km}$ from the city of El Jadida and $17 \mathrm{~km}$ North of the industrial effluents of JorfLasfar. It is characterized by the upwelling causing a ride up of deep water charged with nutritional elements. This station is also characterized by the absence of effluents of different types.

* Station "Jorf-Lasfar" (S3): located at $25 \mathrm{~km}$ South of the city and 1 $\mathrm{km}$ South of industrial effluents. This site is characterized by the presence of 
several industrial units including the phosphate complex Morocco-phosphate III and IV and a thermal power station. This is a large industrial area with the largest port in Africa. The metal concentrations are very high, far exceeding international standards (Essedaoui and Sif, 2001; Merzouki and al., 2009).

\section{Measurements of abiotic and biotic parameters}

The seawater sampling from the study sites have been monthly taken during a period of six months from February 2016 until July 2016 with three samples per station. The abiotic parameters measured in site are the temperature, $\mathrm{pH}$, the conductivity and the luminosity by means of a portatif multiparameter (Odeon Open X) and a luximeter (la-Fayette DT-1300). In absence of the inverted microscope, the estimate of the abundance of planktonic species in seawater samples is carried out by light microscopy as described by Akllal (Akllal and al., 2002).

\section{Sampling and preparation of mussels}

100 individual mussels of the species Mytilus galloprovincialis have been randomly picked per station per month throughout the study period. The samples are taken at low tide at the upper mediolittoral. Mussels are transported to the laboratory in a cooler. Upon arrival, they are brushed, cleaned of their epibionts and sorted by male and female sex and by the size of $5 \mathrm{~mm}$ interval.

\section{Measurement of condition index and the gonadic index}

The condition index (CI) or the flesh index is measured in 100 individual mussels taken from wild mussel and sorted by size class. Among the many formulas, we choose the AFNOR standard (NF V 45056, sep 85), amended in 2000 by an agreement:

\section{CI $=($ Weight of the flesh without water pallial / total weight $) \times 100$}

The mussels are dripped to eliminate intra-valvular water and weighed with a precision balance (RADWAG, AS 160.R2 $\pm 0.1 \mathrm{mg}$ ). The measured weight parameters are:

- Weight of the flesh: it is the weight of the soft parts of the animal after having detached from the shell and rid of intervallic remaining; all fresh visceral mass dripped is weighed. animal.

- Weight of the shell: is weighed after removing the flesh of the

- Total weight : shell weight and the weight of the flesh.

The gonadic index (GI) shows the relationship between a quantitative descriptor of the sexual apparatus and a quantitative descriptor of somatic organs (Regis, 1979). Since the gonads in mussels are mainly contained in 
the mantle lobes, the weight of the mantle can be an approximation of the weight of gonads. The formula used to measure the gonadic index is (Guettaf and San Martin, 1995):

\section{GI = (gonad weight $/$ weight of the flesh without mantle water $) \times 100$ Statistical treatment of results}

Measures of condition index and the gonadic index are expressed as mean \pm standard deviation. The monthly average is obtained by summing the individual measures of each size class. The difference averages are obtained according to a part of prospecting stations and secondly based on month samples is assessed using analysis of variance, which provides the variance through the parameter F Fisher (squares report means groups / square error means) and the degree of significance $\mathrm{p}$ (probability of being outside the confidence interval). The difference is considered significant if $p<0.05$. The Statistica software is used for the statistical treatment.

\section{Results}

\section{Results of abiotic and biotic parameters}

During the study period, measurements of the temperature and $\mathrm{pH}$ show similar fluctuations in all study sites (Fig. 2). Indeed, the highest values of temperature are recorded at $\mathrm{S} 3$ which also has the lowest $\mathrm{pH}$ values varying between 6.4 and 7.5.

According to Figure. 3, the salinity of the seawater presents similar variations in the stations S1 and S2. It is comprised between $30 \%$ ond $35 \%$. However, at the station S3, this value is lower. It oscillates between $28 \%$ and $30 \%$. Furthermore, the intensity of light shows almost the same values in the various stations studied during the study period. There is a progressive increase from February until July-16.

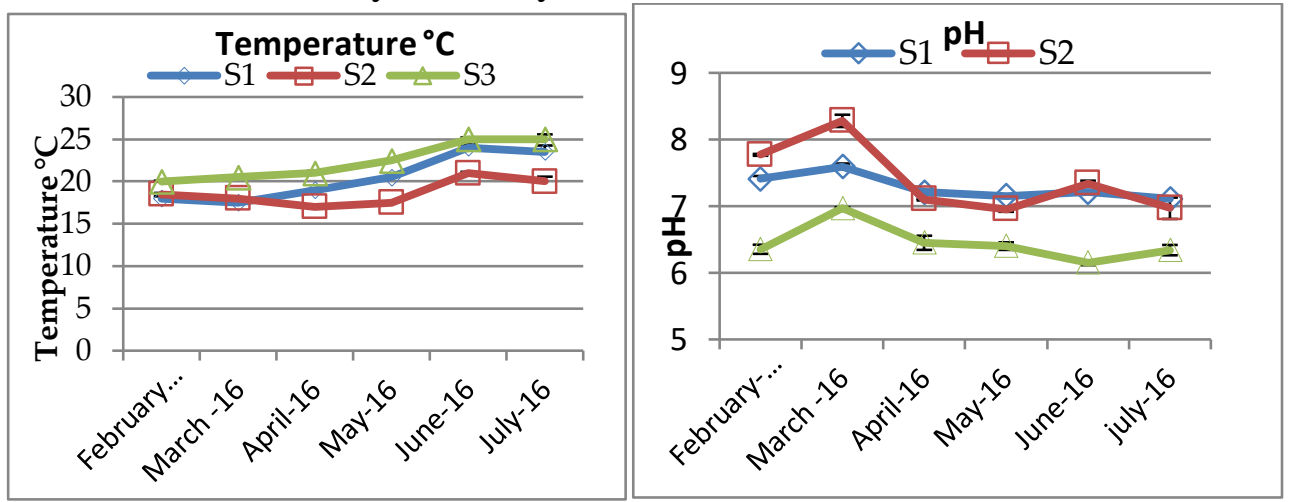

Figure. 2. Spatio-temporal variations of temperature and $\mathrm{pH}$ (mean \pm standard deviation) of water 


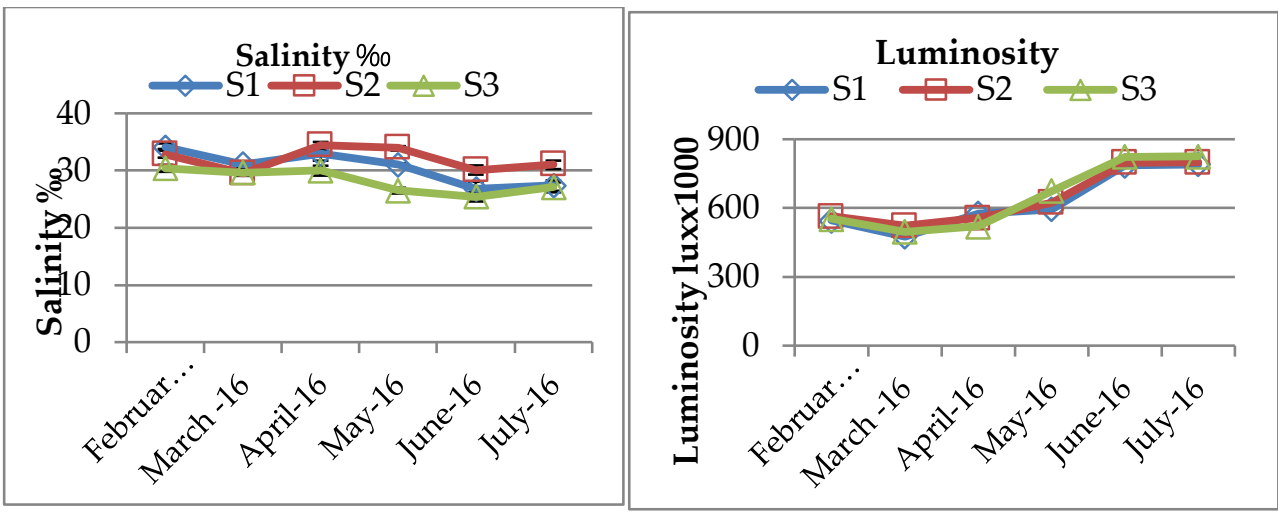

Figure. 3. Spatio-temporal variations of salinity and luminosity (mean \pm standard deviation)

The density of plankton (Fig. 4) shows, in the three stations studied, similar variations illustrated with low values in February, which progressively increase reaching a peak in March and decreases progressively from April. At the stations S1 and S2, the detected density varies between 6 ind./0.1 ml to 13 ind. $/ 0.1 \mathrm{ml}$. Moreover, the station S3 present significantly lower values $(\mathrm{p}<0.001)$ compared to two other stations throughout the study period ( 2 to 6 ind./ $/ 0.1 \mathrm{ml})$.

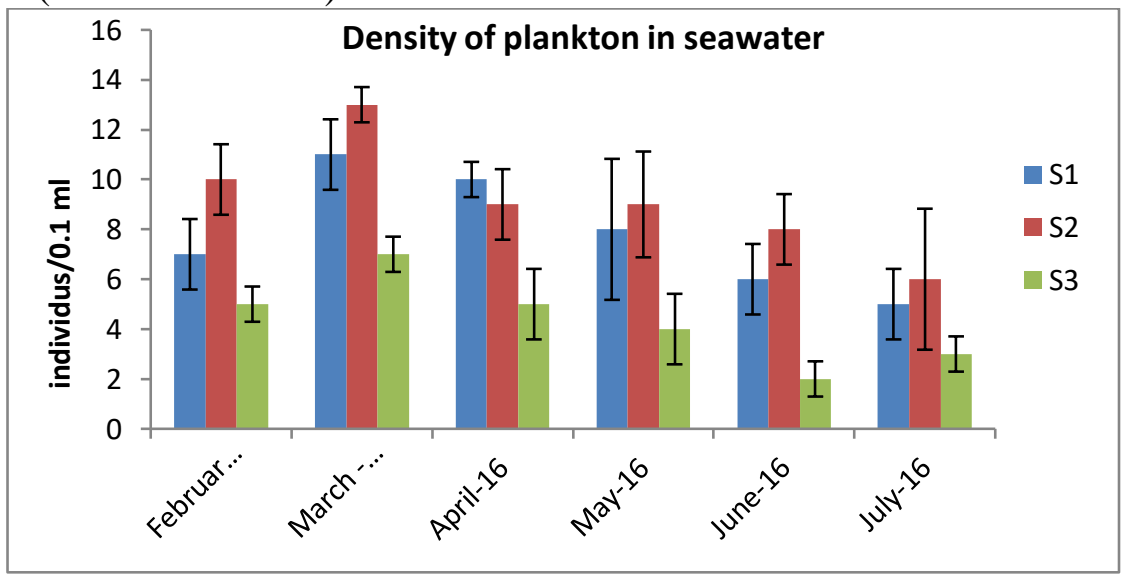

Figure 4. Spatio-temporal variations of plankton density (mean \pm standard deviation)

\section{Condition index (CI)}

The condition index is measured in the mussels of the most frequent size classes studied at stations namely, [25-30] [30-35] [35-40] and [40-45].

\section{Comparison of the condition index between different size classes in the three stations:}

In mussels from station 1 (Fig. 5), the CI has very highly significant variation $(\mathrm{p}<0.001)$ at the date of sampling. Indeed, the highest values are recorded in May-16 (37.2 \pm 4.90 and $35.2 \pm 3.30$ respectively for the size 
classes [35-40] and [30-35]) and lowest values in the month of March -16 $(21.1 \pm 1.70$ and $24.4 \pm 2.90$ respectively for the size classes [40-45] and [35-40]). Moreover, at the stations S2 and S3 (Fig. 5, 6), CI shows a nonsignificant difference between the different months of levy, seasonal fluctuations are not very marked with a maximum of $24.4 \pm 3.30$ [30-35] and $23.5 \pm 0.01$ [25-30] respectively at S3 and S2 and a minimum of $17.2 \pm 1.90$ [40-45] $18.1 \pm 2.40$ [40-45] respectively at S3 and S2. However, in the three prospected stations, no significant difference in the CI is recorded among size classes [25-30] [30-35] [35-40] and [40-45] during the study period.

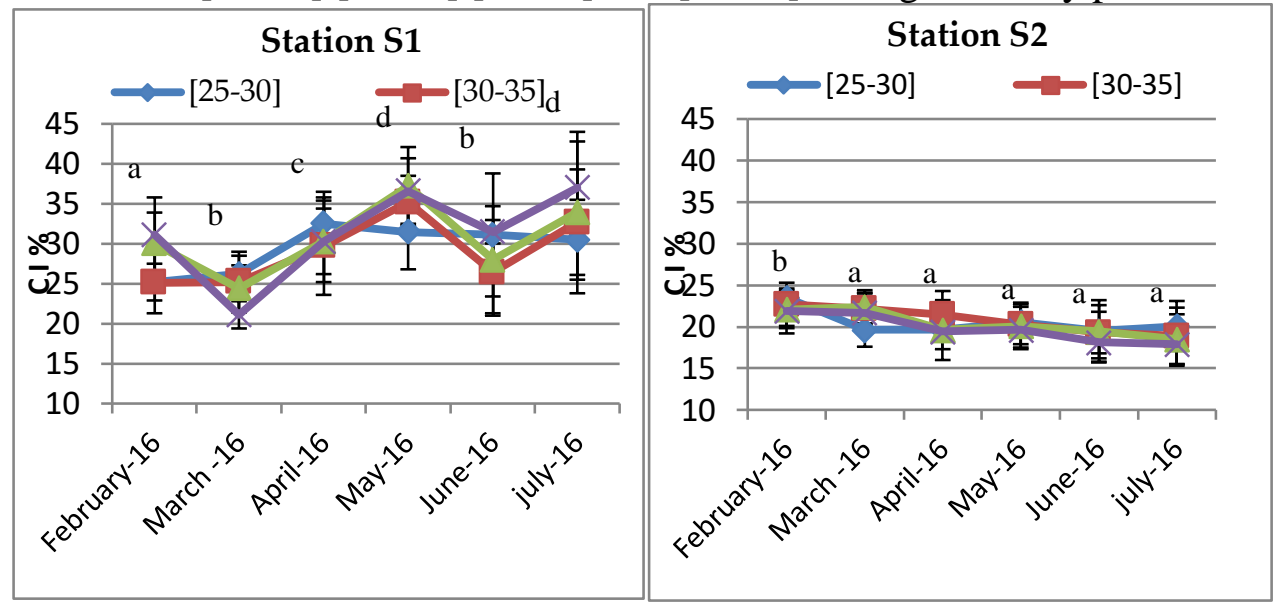

Figure 5. Condition index (mean \pm standard deviation) of the different size classes of stations S1 and S2. (For each month, size classes with same letter were not significaltly different)

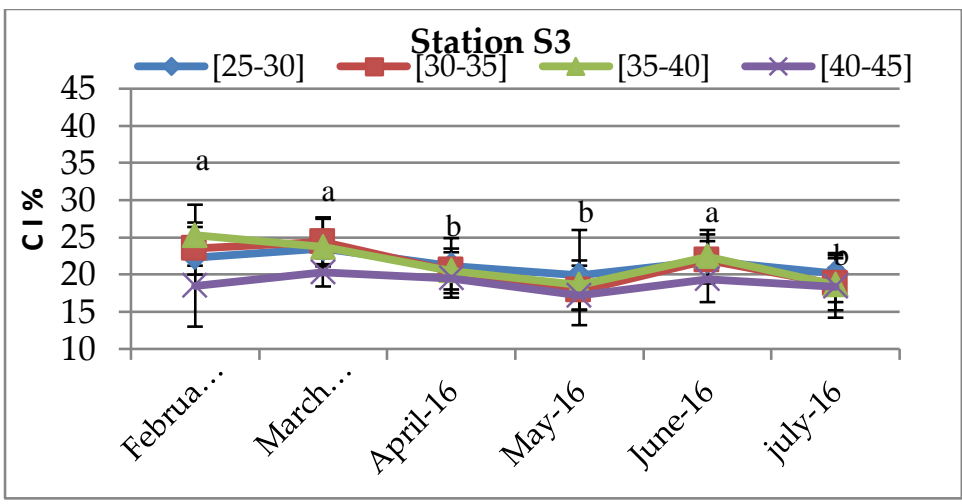

Figure 6. Condition index (mean \pm standard deviation) of the different size classes of station 3.(For each month, size classes with same letter were not significantly different)

\section{Comparison of the condition index of the most frequent size classes of mussel among different stations studied:}

Statistical analysis of the CI results reveals a significant difference ( $\mathrm{p}<0.001$ ) between S1, S2 and S3 (Fig. 7). Indeed, among the most frequent size class mussels namely [25-30] [30-35] [35-40] and [40-45], the mean of 
the CI oscillate between 30.1 and 37.5 during the months of April, May, June, and July-16 in S1. However, in S2 and S3, averages do not exceed 21.8 during the same study period.

In $\mathrm{S} 1$, a decline in CI is observed in the size classes [35-40] and [4045] during the month of March-16 and in the size classes [25- 30] and [3035 ] in the months of February and March-16 as compared to other months of sampling (Fig. 8). However, in S2 and S3, the comparison between the averages of the $\mathrm{CI}$ registered in size classes studied shows no difference (NS). These averages vary between 17.2 - 25.3 for S3 and 18.1-23.5 for S2.
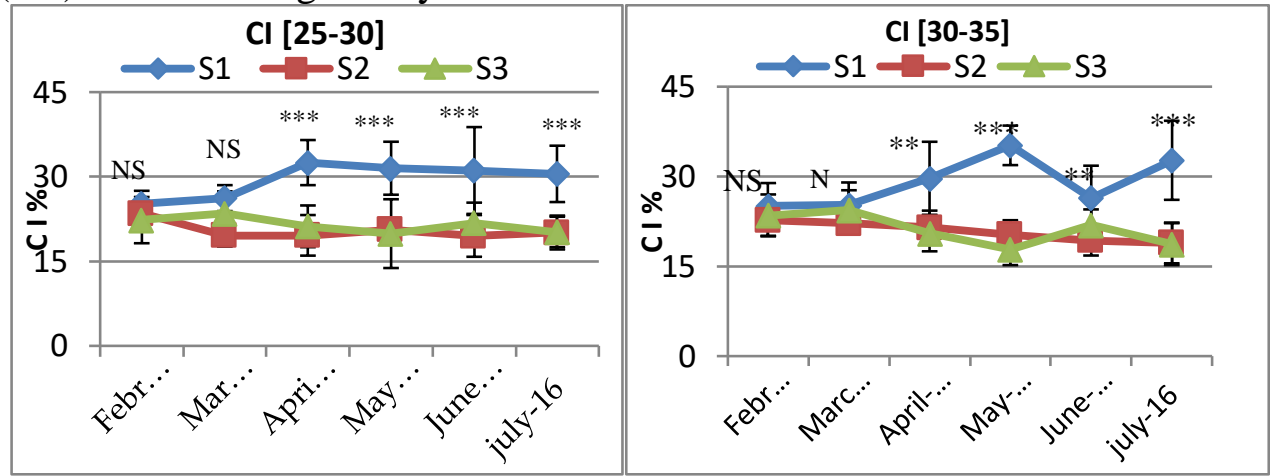

Figure. 7. Spatio-temporal variations of the condition index for the class [25-30] and [3035]. (*: $\mathrm{p}<0,05 ; * *: \mathrm{p}<0,01 ; * * *: \mathrm{p}<0,001 ;$ NS : Not Significant)

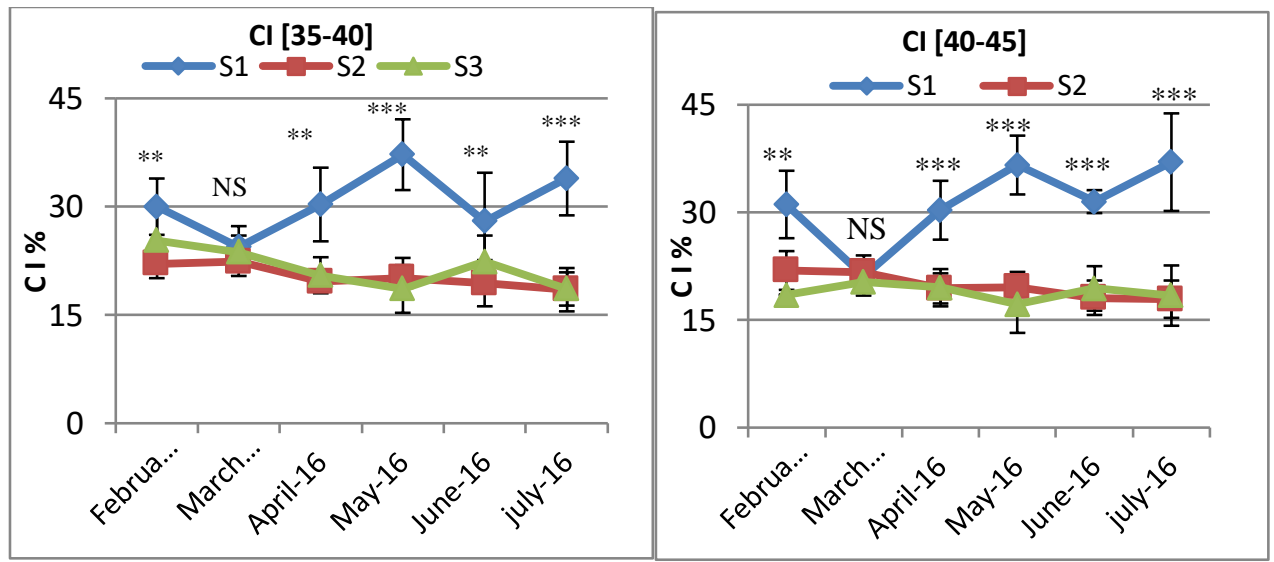

Figure. 8. Spatio-temporal variations of the condition index for the class [35-40] and [4045]. (*: $\mathrm{p}<0,05 ; * *: \mathrm{p}<0,01 ; * * *: \mathrm{p}<0,001 ;$ NS : Not Significant)

\section{Gonadic index (GI)}

Comparison of gonadic index between different size classes in the three stations studied:

According to Table 1, the size class mussels [25-30] saves a lower GI compared to other size classes in the three stations studied. The index varies between 15.3 and 19.8 respectively recorded during the months of June and 
February-16 at the station S1 and between 4.2 and 16.4 at the stations S2 and S3. Moreover, the size class mussels [40-45] from the stations S2 and S3 have higher values of GI compared to other size classes during the months of February, March, April-16. In contrary, at station S1, the size class mussels [30-35] shows a higher GI during the months of February, May and June-16 as compared to other size classes. Note that the GI measured presents significant temporal variations between different samples within the same station.

Table 1 : Gonadic index (mean \pm standard deviation) of the different size classes of stations $\mathrm{S} 1, \mathrm{~S} 2$ and $\mathrm{S} 3$.

\begin{tabular}{|c|c|c|c|c|c|c|c|}
\hline & Size Classes & $\begin{array}{c}\text { February- } \\
16 \\
\end{array}$ & $\begin{array}{c}\text { March - } \\
16\end{array}$ & April-16 & May-16 & June-16 & July-2016 \\
\hline \multirow{4}{*}{ 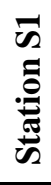 } & [25-30] & $19.8 \pm 2.5$ & $18.5 \pm 2.2$ & $18.6 \pm 6.0$ & $17.4 \pm 6.6$ & $15.3 \pm 1.5$ & $15,2 \pm 7.0$ \\
\hline & [30-35] & $23.7 \pm 8.3$ & $25.7 \pm 7.2$ & $20.2 \pm 3.6$ & $28.0 \pm 10.8$ & $22.6 \pm 8.4$ & $28,6 \pm 6.1$ \\
\hline & {$[35-40]$} & $20.2 \pm 7.9$ & $25.6 \pm 6.5$ & $27.8 \pm 8.2$ & $23.4 \pm 8.3$ & $20.1 \pm 9.6$ & $29,7 \pm 6.8$ \\
\hline & [40-45] & $18.3 \pm 6.1$ & $20.8 \pm 6.9$ & $25.5 \pm 7.2$ & $25.4 \pm 8.1$ & $23.1 \pm 6.3$ & $29,1 \pm 6.7$ \\
\hline \multirow{4}{*}{ 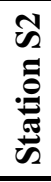 } & [25-30] & $9.1 \pm 4.2$ & $8.2 \pm 2.3$ & $4.1 \pm 2.1$ & $5.3 \pm 2.3$ & $4.2 \pm 1.0$ & $12,7 \pm 4.2$ \\
\hline & [30-35] & $10.6 \pm 5.4$ & $13.9 \pm 6.6$ & $9.8 \pm 5.8$ & $8.9 \pm 5.6$ & $3.7 \pm 2.1$ & $12,0 \pm 5.7$ \\
\hline & [35-40] & $12.5 \pm 4.7$ & $18.4 \pm 8.8$ & $8.5 \pm 4.4$ & $9.5 \pm 5.3$ & $7.5 \pm 4.2$ & $12,9 \pm 4.9$ \\
\hline & [40-45] & $18.0 \pm 8.5$ & $20.0 \pm 6.5$ & $13.8 \pm 6.2$ & $12.4 \pm 5.1$ & $9.5 \pm 3.2$ & $15,4 \pm 5.8$ \\
\hline \multirow{4}{*}{ 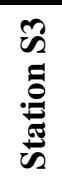 } & [25-30] & $16.4 \pm 6.3$ & $15.2 \pm 4.2$ & $11.9 \pm 5.2$ & $4.5 \pm 2.2$ & $7.7 \pm 4.5$ & $15,3 \pm 8.1$ \\
\hline & [30-35] & $19.7 \pm 10.2$ & $15.2 \pm 7.6$ & $13.1 \pm 7.4$ & $6.8 \pm 3.5$ & $10.3 \pm 4.5$ & $11,0 \pm 6.1$ \\
\hline & [35-40] & $19.9 \pm 6.4$ & $18.5 \pm 2.1$ & $13.2 \pm 5.1$ & $15.9 \pm 2.4$ & $12.5 \pm 4.6$ & $12,1 \pm 3.4$ \\
\hline & {$[40-45]$} & $21.5 \pm 7.9$ & $23.5 \pm 6.3$ & $18.4 \pm 6.2$ & $15.9 \pm 5.3$ & $13.1 \pm 5.9$ & $26,4 \pm 5.3$ \\
\hline
\end{tabular}

Comparison of gonadic index between various stations studied in the most frequent size classes of Mussel:

Measurements of the GI performed in the size class of mussels [2530] [30-35] [35-40] [40-45] taken in $\mathrm{S} 1$ are significantly higher ( $\mathrm{p}<0.001$ ) compared to mussels from S2 and S3 near industrial effluents during the months of March, April, May and June-16 (Fig. 9 and 10). These values vary between $20.2 \pm 3.6$ and $28.0 \pm 10.8$ in the size class mussels [30-35] sampled in $\mathrm{S} 1$ and do not exceed $13.9 \pm 6.6$ in $\mathrm{S} 2$ and $15.7 \pm 6.1$ in S3. The comparison of the average GI mussels from stations S2 and S3 shows no significant difference in the [30-35] size classes and [35-40] in the months of March and April-16 and for size class [25-30] in the months of May and June. Note that in S3, the GI is relatively higher compared to the S2 in most size classes studied. 


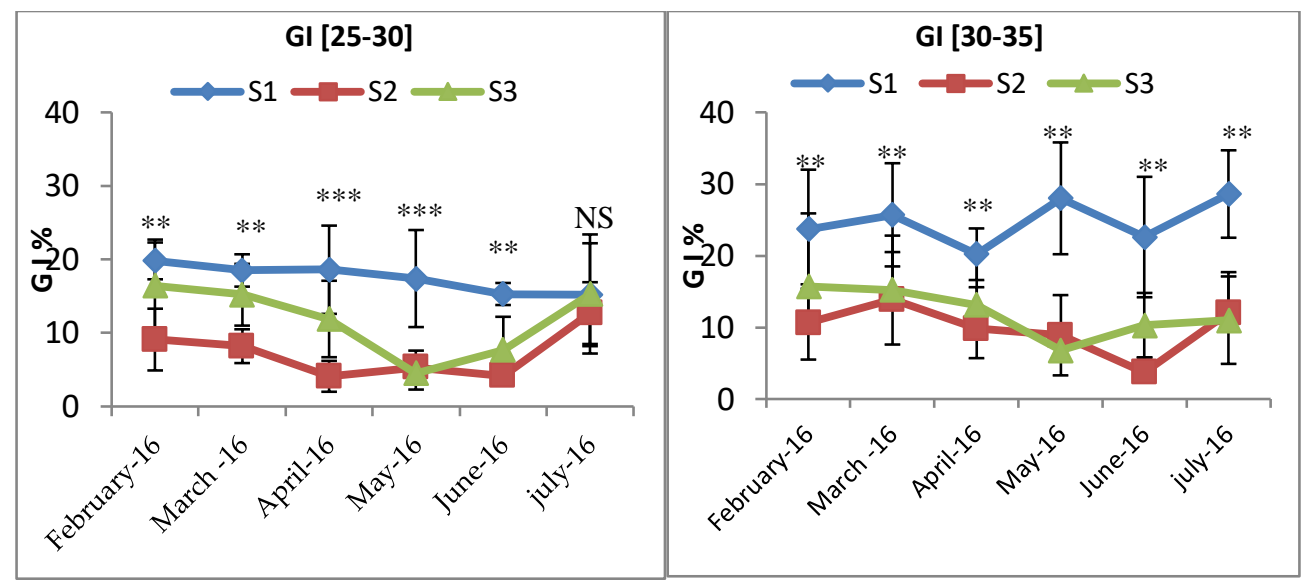

Figure. 9. Spatio-temporal changes in the gonadic index (mean \pm standard deviation) for the class [25-30] and [30-35]. (*: $\mathrm{p}<0,05 ; * *: \mathrm{p}<0,01 ; * * *: \mathrm{p}<0,001 ;$ NS : Not Significant)
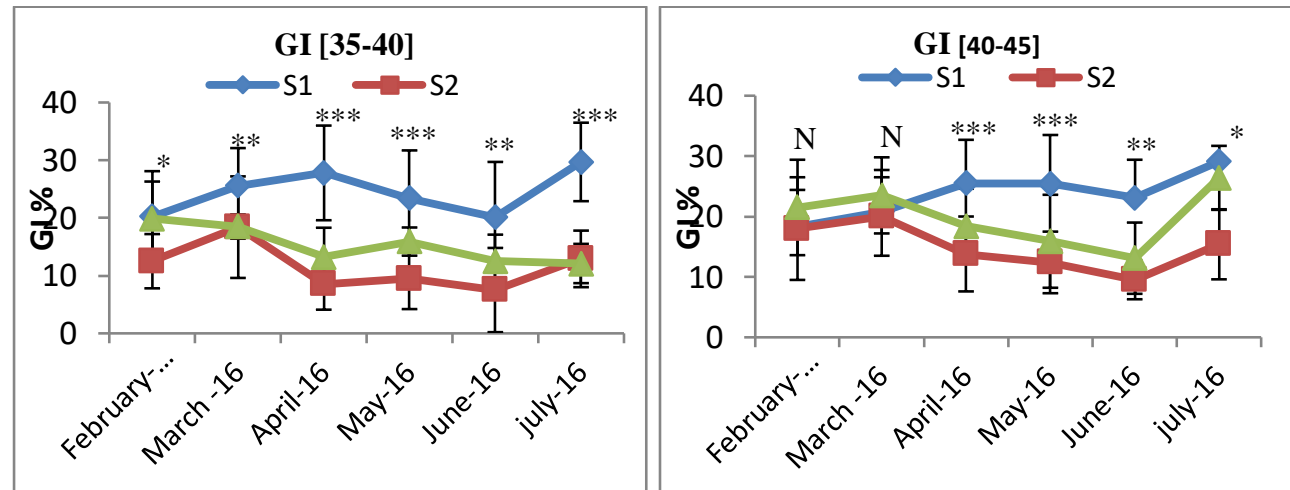

Figure. 10. Spatio-temporal variations of the gonadic index (mean \pm standard deviation) for the class [35-40] and [40-45]. (*: $p<0,05 ; * *: p<0,01 ; * * *: p<0,001 ;$ NS : Not

Significant).

\section{Comparison of spatial and temporal variation of condition index and the gonadic index}

The comparison of the evolution of the GI and the CI (Fig. 11) shows that in S1 the increase of GI is accompanied by an increase of CI, except for the month of March-16 where gonadic development is accompanied by a decrease in the level of development of the flesh of the animal. On the other hand, from the month of April we observe a simultaneous increase in both indices up to June-16.

In size class mussels [35-40] in $\mathrm{S} 1$, for example, the gonad maturation phase is characterized by an increase in CI that passes from 24.8 \pm 3.3 in March to $35.8 \pm 4.5$ in May. The falling in the value of the CI in March corresponds to the laying phase which is spread out between February and March-16. 


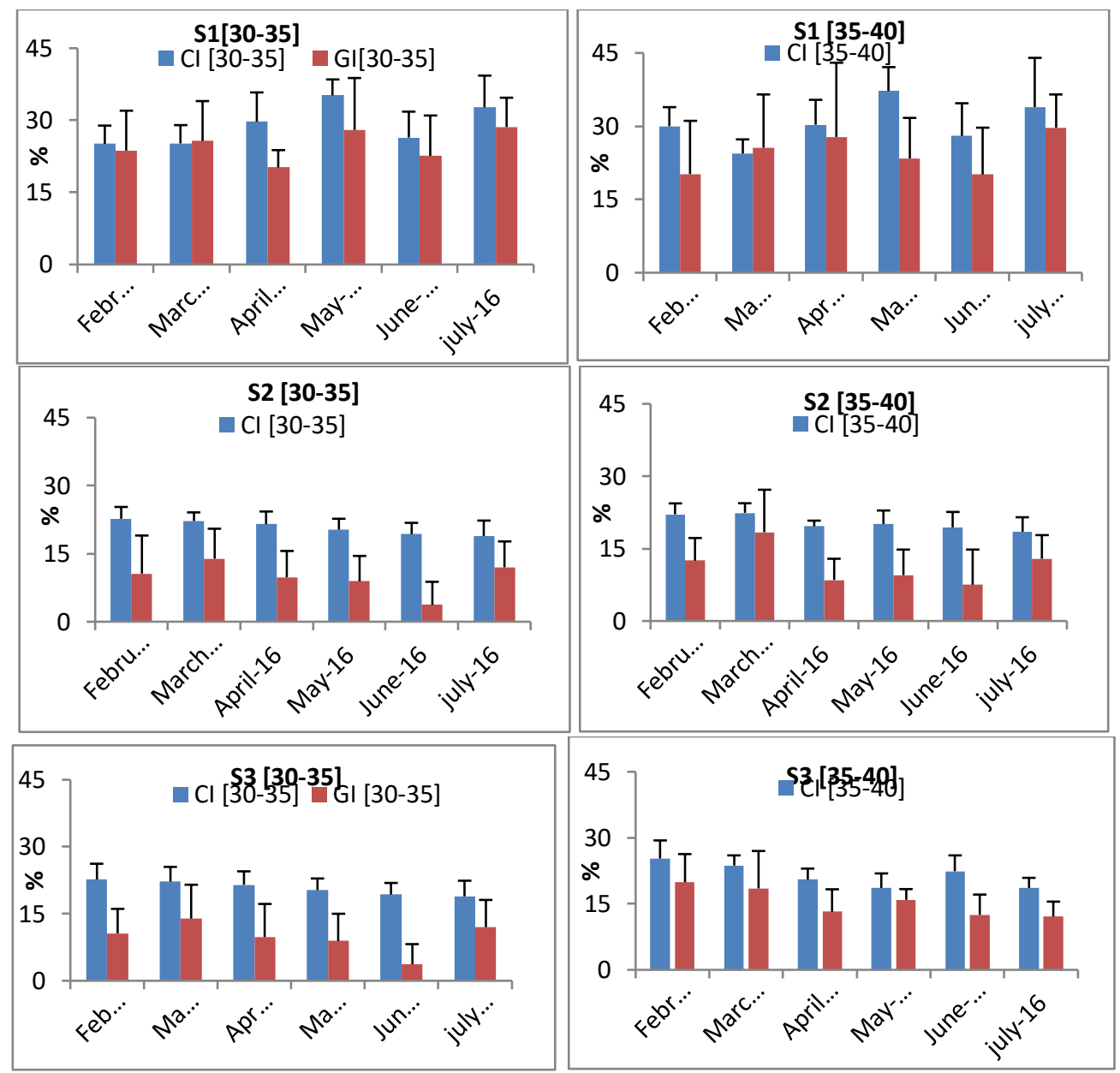

Figure. 11. Changes in the condition index and gonadic index (mean \pm standard deviation) during the study period.

In mussels from S2 [35-40], gonads come into maturation phase in February (GI goes from $15.5 \pm 8.5$ in February to $18.9 \pm 8.1$ in March). The spawning phase follows from March to June (the CI from $21.6 \pm 2.4$ to 19.1 \pm 2.8 ).

At Jorf-Lasfar (S3), a gametogenesis phase takes place between February and March-16. GI goes from $20.0 \pm 8.9$ in February to $24.5 \pm 10.3$ in March. The fall in the value of the CI between March and May-16 corresponds to a nesting phase which lasts until May. The increase in CI values from May to June-16 corresponds to a second phase of maturation of the gonads. 


\section{Discussion}

Monthly statements of water temperatures of the three stations (Hawzia, Sidi Bouzid and Jorf-Lasfar) show the existence of two distinct periods: one of low temperature from February to March, with a minimum of 17.5 ${ }^{\circ} \mathrm{C}$ recorded in February, and a second at high temperature, which is spanning from the March to July with a maximum of $25^{\circ} \mathrm{C}$ in the polluted station (S3). This temperature difference is due to industrial effluents of the chemical complex. Regarding salinity, it shows seasonal fluctuations with lower values in S3. This is explained by the high dilution by high intakes of water, originating from discards. Concerning $\mathrm{pH}, \mathrm{S} 3$ shows acid values which can be explained by the existence of phosphogypsum effluent from Morocco-phosphate complex III and IV.

Analysis of physicochemical parameters of the water is of major importance in the study of the growth and reproduction of the mussel Mytilus galloprovincialis. Indeed, the temperature is directly involved in the biological process. The molds are poikilothermic (Lubet, 1959). The temperature variations are insufficient to explain alone the punters (Incze and al., 1980), but they act as a "trigger" on animals that already reach sexual maturity. Therefore, the seasonal variations in this parameter must be taken into account (Amiard and al., 1995; Longstone and Spence, 1995).

The plankton levels show high values during spring and low in winter and summer periods. In a functioning ecosystem study, the phytoplankton density and the observed fluctuations are strongly influenced by the temperatures and light intensities. The low content of phytoplankton, registered in cold periods, is explained by low temperatures. The high amplitude of temperature variations plays a direct role in the succession of planktonic species. Plankton blooms are an essential food intake to the mold; they stimulate sexual maturation, both in importance by the suddenness of their appearance (Cartier and al., 2004).

The results of measuring the condition index in the mussel Mytilus galloprovincialis show that this index is better in S1 (Hawzia). These values can be explained not only by the probable appearance of phytoplankton blooms and thereby the abundance of food but also the likely achievement of the optimum physiological temperature that allow a better metabolization of the products of digestion. According Romeo and al. (2000), the condition index is associated with water temperature and corresponds to filling ratio of the shell by soft tissue. It therefore informs about the nutritional and physiological state of the animal. The growth is characterized by an increase in size and weight depending of time and environmental variables. However, in bivalve molluscs, especially in mussels, reproduction-related processes disrupt this pattern in a temporary accumulation of large reserves that are 
subsequently converted into gametes then expelled during spawning, causing a sudden loss of weight (Lubet, 1981).

It is also noted that during the sexual activity phase, the individual variations are important and would, according Dridi and al. (2008), be probably generated by physiological changes associated with gametogenesis and issuance gametes. In bivalves, several factors such as physical and nutritional status of the environment (Utting 1986) and physiological parameters (Bayne and al., 1999) would influence their speed linear and weight growth.

Observation of high values of this index in winter is explained by the accumulation of reserves in the gonads that come into sexual maturity phase. However, at Sidi Bouzid (S2) and Jorf-Lasfar (S3) stations, we find that the values of this index are low compared to Hawzia station (S1). This difference is probably due to the time spent by the animal in the water which is important in these two stations. Thereby pushing these animals to spend their energy in the thermoregulatory process instead of filling.

The reduction in condition index would correspond to spawning phases. Similar observations are reported by many authors (Lasiak and Barnard, 1995; Mc Quaid and Lawries, 2005). Other authors explain that the decline in the index is due to poor trophic conditions or following an egg that spawn weight loss (Barille, 1996; Dorange and al,. 1989; Paulet and al., 1992) or following metal pollution that causes the fall of the degree of filling of shells (Merzouki and al., 2009).

\section{Conclusion}

It is necessary to point out that the results of condition index and the gonadic index obtained in mussels from S3, whose cadmium concentrations in the digestive gland of the bivalve are higher than the norms (Essedaoui and al., 2001), are similar to that obtained from S2. This station is located at $17 \mathrm{~km}$ North of effluents industrials and characterized by the absence of any type of industrial or domestic pollution. This result makes us assumed that metal pollution has no effect on both the growth and reproduction of Mytilus galloprovincialis. The mussels have probably adapted to local conditions by the high accumulation of toxic metals and their storage under metallothioneins form (Amiard and Amiard-Triquet; 2008). In response to stress, certain species promote a proactive strategy others a reactive strategy. One can expect a high variability of physiological responses triggered by a stressor (Wenderlaar and Balm, 1999). This study will be completed by the study of the impact of pollution on the population dynamics of Mytilus galloprovincialis in the coastal region of El Jadida Morocco. 


\section{References:}

1. Akallal, R., Billard. C., Fresnel. J., Givernaud. T., Mouradi. A. 2002. Contribution à l'étude du phytoplancton de la côte atlantique marocaine. I - Espèces récurrentes, proliférantes ou potentiellement toxiques. Mar.Life vol. 12(1.2) : 11-20.

2. Amiard, J. C., Amiard-Triquet, C. 2008. Les biomarqueurs dans l'evaluation de l'état écologique des miliieux aquatiques. Lavoisier Tec \& Doc, Paris 375pp.

3. Amiard J.C., Haynes, D., Mosse, P., Levay, G. 1995. The use of transplanted cultured mussels (Mytilus edulis) to monitor pollutants along the Ninety Mile Beach, Victoria, Australia-I. Extractable organohalogens (EOX), Marine Pollution Bulletin. 30 (7): 463-469.

4. Barille, A.L. 1996. Contribution à l'étude des potentialités conchylicoles de Pertuis Breton. Thèse de doctorat, Universirté d'Aix-Marseille II, 243 pp.

5. Bayne, B. L., Svensson, S., Nell J. A. 1999. The physiological basis for faster growth in the sydney roch oyster, Saccostrea glomerata. Boil.bull.197 (3):377-387

6. Cartier, S., Pellerin-Massicotte J., Fournier M., Tamigneaux E., Girault L., Lemaire N. 2004. Use of an index based on the blue mussel (Mytilus edulis and Mytilus trossulus) digestive gland weight to assess the nutritional quality of mussel farm sites. Aquaculture 241: 633-654.

7. Dorange, G., Paulet, Y. M., Le Pennec, M., and Cochard, J. C. 1989. Critères d'évaluation de la qualité des ovocytes émis par Pecten maximus (Mollusque Bivalve). Comptes Rendus de l'Académie des Sciences, Paris, 309 (III): 113-120.

8. Dridi, S.,Romane, M.S., Cafsi ,M. 2008 Croissance et variations saisonnières de de l'huître Crassostrea gigas cultivée dans la lagune de Bizete, Tunisie. Belg. J. Zool. 138 (2), 158-169.

9. Essedaoui, A., Kerambrun, P., Alliot, E.et Sif J. 2001. Impact de la pollution métallique sur l'activité des hydrolases au niveau de la glande digestive du mollusque Mytilus galloprovincialis de la région de Jorf-Lasfar (Maroc). Mar. Life. 11 (1-2): 21-31.

10. Farrington, D. P. 1991. Biogeochemical processes governing exposure and uptake of organic pollutant compounds. In Aquatic Organisms Environmental Health perspectives. IVI (90): 75-84.

11. Ferssiwi, A., Sif, J., El Hamri, H., Rouhi, A, Amiard, J.C. 2004. Contamination par le cadmium de l'Annélide Polychète Hediste diversicolor dans la région d'El Jadida (Maroc) : implication des protéines type métallothionéines. J. Rech. Océanogr. 29 (3-4): 59-64. 
12. Guettaf., M., et San Martin, G. A. 1995. Contribution à l'étude de la variabilité de l'indice gonadique de l'oursin comestible Paracentrotus lividus (Echinodermata : Echinoidea) en Méditerranée Occidentale. Vie Milieu. 45 (2): 129-137.

13. Incze, M. L. S, Lutz, R. A., Walting M. L. 1980. Relationship between effects of environmental temperature and season on growth and mortality of Mytillus edulis. Mar.Biol 58: 147-156.

14. Kaimoussi, A.; Chafiq, A., Mouzdahir, A. et Bakkas, S. 2001. Impact de la pollution industrielle sur la zone côtière du Jorf Lasar (océan Atlantique marocain) : la moule comme indicateur de la contamination métallique. Comptes rendus de l'académie des sciences séries II- Earth and Planetary Science. 333 (6) : 337-341.

15. Le Pennec, M. 1981. Les méthodes expérimentales induisant la ponte chez les mollusques bivalves marins. Haliotis 11 : $139-155$.

16. Lasiak, T. A., Barnard, T. C. E. 1995. Recruitment of the brown mussel Perna perna onto natural substrata: a refutation of the primary/secondary settlement hypothesis. Mar. Ecol. Prog. Ser. 120: 147-153.

17. Longston,W.J., Spence S.K. 1995. Biological factors involved in metal concentrations observed in aquatic organisms. Eviron. Sci. Tech. 26: 407-467.

18. Lubet, P. 1959. Recherches sur le cycle sexuel et l'émission des gamètes chez les mytilidés et les pectinidés (Moll. Bival). Rev. Trav. Inst. Pêche Marit. 23 (4): 389- 548.

19. Lubet, P. 1981. Action de la température sur le cycle de reproduction des lamellibranches. Extrait Bull. Soc. Zool. France 106 (3): 283-291.

20. Mc Quaid, C. D., Lawrie, S. M. 2005. Supply-side ecology of the brown mussel Perna Perrna: an investigation of spasial and temporal variation in, and coupling between gamete release and larval supply. Mar.Biol. 147(4): 955-936.

21. Merzouki, M.,. Talib, N.,. Sif, J. 2009. Indice de condition et teneurs de quelques métaux $(\mathrm{Cu}, \mathrm{Cd}, \mathrm{Zn}$ et $\mathrm{Hg})$ dans les organes de la moule Mytilus galloprovincialis de la côte d'El Jadida (Maroc) en mai et juin 2004. Bull. Inst. Sci. Rabat.31 (1) : 21-26.

22. Paulet, Y.M., Dorange, G., Cochard, J. C. 1992. Le Pennec. M. Reproduction et recrutement chez Pecten maximus. Ann. Inst. Oceanogr. Paris. 68(1-2) : 45-64.

23. Regis.M.B. 1979. Analyse des fluctuations des indices physiologiques chez deux échinoîdes (Paracentrotus lividus Lamarck) et Arbacia lixula (L.), du golfe de Marseille.Tethys 9 (2) : 167-181.

24. Romeo, M., Bennani, N., Gnassia-Barelli, N., Lafaurie,M., Giard, J. P. 2000. Cadmium and copper display different responses towards 
oxidative stress in the kidney of the sea bass Dicentrarchus labrax. Aquat. Toxicol. 48 (2-3): 185-194.

25. Utting, SD. 1986. A preliminary study on growth of Crassostrea gigas larvae and spat in relation to dietary protein. Aquaculture. 56 (2): 123-138.

26. Wendelaar, B. S. E., Balm, P. H. M. 1999. Histological and histopathological effects of stress. In P. H. M. Balm (Ed) Stress Physiology in Animals. Academic Press, Sheffield, pp 178-204. 